\title{
The effect of support on $\mathrm{RhFe} / \mathrm{Al}_{2} \mathrm{O}_{3}$ for ethanol synthesis via $\mathrm{CO}$ hydrogenation
}

\author{
Fang Li ${ }^{1}\left[\right.$ C $\cdot$ Weixing Qian ${ }^{2}$
}

Received: 27 January 2021 / Accepted: 12 July 2021 / Published online: 21 July 2021

(c) The Author(s) 2021

\begin{abstract}
Different alumina samples prepared with sol-gel, chemical precipitation and hydrothermal synthesis were used as supports of Fe-promoted Rh-based catalysts for ethanol synthesis via $\mathrm{CO}$ hydrogenation. The samples were characterized by means of $\mathrm{N}_{2}$-adsorpotion, XRD, $\mathrm{H}_{2}$-TPR, XPS, STEM, $\mathrm{H}_{2}$-TPD, DRIFTS, $\mathrm{H}_{2}$ and $\mathrm{CO}$ chemisorption. The results indicated that the $\mathrm{Al}_{2} \mathrm{O}_{3}$ prepared by hydrothermal synthesis exhibited nano-fiber morphology and constituted of mixed crystal phases, while $\mathrm{Al}_{2} \mathrm{O}_{3}$ prepared by sol-gel and chemical precipitation shows no changes of morphology and crystal phases compared with the commercial $\mathrm{Al}_{2} \mathrm{O}_{3}$. In addition, nano-fiber $\mathrm{Al}_{2} \mathrm{O}_{3}$-supported $\mathrm{Rh}$-based catalyst shows higher ethanol selectivity, which is ascribed to the lower metal-support interaction, higher dispersion and stronger $\mathrm{CO}$ insertion ability.
\end{abstract}

Keywords Ethanol synthesis $\cdot \mathrm{Al}_{2} \mathrm{O}_{3} \cdot$ Interaction $\cdot$ DRIFTS

\section{Introduction}

Ethanol synthesis via syngas directly has attracted a great deal of attentions in recent years [1-3]. However, there is still a challenge for improving the selectivity of catalysts. Fe-promoted Rh-based catalysts have been reported to work well for ethanol synthesis [4-7]. For instance, Fukushima et al. [8] found the addition of $\mathrm{Fe}$ to $\mathrm{Rh} / \mathrm{SiO}_{2}$ can enhance the formation of intermediate species for ethanol synthesis by high-pressure FT-IR study. A good choice of support would be helpful to explore the potentiality of Fe-promoted Rh-based catalysts. $\mathrm{Al}_{2} \mathrm{O}_{3}$ had been investigated as the support of Rh-based catalysts since it is extensively used as commercial carrier [9]. Burch et al. [10] found that the $\mathrm{Al}_{2} \mathrm{O}_{3}$-supported $\mathrm{Rh}$-based catalysts exhibited excellent ethanol selectivity. However, Chen et al. [9] proposed that the $\mathrm{Al}_{2} \mathrm{O}_{3}$ support was not the best choice for Rh-based catalysts since it had strong interaction with the metals. The above

Fang Li

zls9390@163.com

1 School of Chemical and Environment Engineering, Anhui Polytechnic University, Wuhu 241000, Anhui, China

2 Engineering Research Center of Large Scale Reactor Engineering and Technology, Ministry of Education, East China University of Science and Technology, No. 130, Meilong Road, Shanghai 200237, China two opposite findings suggest that the interaction between metal and $\mathrm{Al}_{2} \mathrm{O}_{3}$ should be adjusted carefully to meet the requirement of ethanol synthesis from syngas.

The interaction between $\mathrm{Al}_{2} \mathrm{O}_{3}$ support and metal depends on the nature of the $\mathrm{Al}_{2} \mathrm{O}_{3}$, such as the texture, crystal and chemical properties. In the reaction of $\mathrm{CH}_{4}$ reforming, the good performance was presented on the nano-fiber $\mathrm{Al}_{2} \mathrm{O}_{3}$-supported $\mathrm{Pt}$ catalysts, Garc1'a-Die'guez et al. [11] ascribed it to the mixed crystal of the $\mathrm{Al}_{2} \mathrm{O}_{3}$ support prepared by hydrothermal synthesis. Zhang et al. [12] concluded that different crystal structures of $\mathrm{Al}_{2} \mathrm{O}_{3}$ could decrease the metal-support interaction due to its modified hydroxyl group. For supported Rh-based catalyst, it is reported that the weakly $\mathrm{H}$-bonded surface hydroxyls of $\mathrm{SiO}_{2}$ have an important effect on the interaction between $\mathrm{Rh}$ and promoter [13]. Therefore, a comprehensive understanding of the interaction between support and active metals is very important for design of the supports for Rh-based catalysts. Moreover, this understanding would be strengthened if we know the effect of support at some curial steps, such as $\mathrm{CO}$ adsorption, dissociation and hydrogenation, during ethanol formation.

In this study, three $\mathrm{Al}_{2} \mathrm{O}_{3}$ supports were prepared by sol-gel, chemical precipitation and hydrothermal synthesis. The commercial $\gamma-\mathrm{Al}_{2} \mathrm{O}_{3}$ was also used as reference. The typical physical-chemical properties of samples were characterized by different techniques, such as X-ray 
diffraction (XRD), nitrogen physisorption, $\mathrm{H}_{2}$ temperatureprogrammed reduction ( $\mathrm{H}_{2}$-TPR), $\mathrm{H}_{2}$ and $\mathrm{CO}$ chemisorption, $\mathrm{H}_{2}$ temperature-programmed desorption $\left(\mathrm{H}_{2}-\mathrm{TPD}\right)$, $\mathrm{X}$-ray photoelectron spectroscopy (XPS) and high resolution scanning transmission electron microscopy (STEM). Furthermore, diffuse reflectance infrared Fourier-transform spectroscopy (DRIFTS) was used to determine CO adsorption, hydrogenation behavior, and surface hydroxyl group of samples.

\section{Experimental}

\section{Support and catalyst preparation}

Alumina samples were prepared by chemical precipitation, sol-gel and hydrothermal synthesis methods, denoted as $\mathrm{Al}-\mathrm{CP}, \mathrm{Al}-\mathrm{SG}$ and $\mathrm{Al}-\mathrm{HS}$, respectively. Commercial $\boldsymbol{\gamma}-\mathrm{Al}_{2} \mathrm{O}_{3}$ was abbreviated as Al-CM. Al-CP was prepared in the following procedure: $45.0 \mathrm{~g}$ of $\mathrm{Al}\left(\mathrm{NO}_{3}\right)_{3} \cdot 9 \mathrm{H}_{2} \mathrm{O}$ was dissolved in $250 \mathrm{~mL}$ of de-ionized water with strong agitation to form transparent solution. Simultaneously, the above solution and aqueous ammonia ( $2.5 \mathrm{wt} \%$ ) solution were added dropwise into a beaker at constant $\mathrm{pH}$ with magnetic stirring. After that, the suspension was aged for $12 \mathrm{~h}$ at room temperature, and then filtered, washed with de-ionized water many times until no change of $\mathrm{pH}$. At last, the obtained precipitate was dried at $110{ }^{\circ} \mathrm{C}$ for $12 \mathrm{~h}$, and then calcined at $500{ }^{\circ} \mathrm{C}$ for $4 \mathrm{~h}$. For the preparation of Al-SG, alumina sol was first prepared. Aluminum isopropoxide was added slowly to the water and kept at $90{ }^{\circ} \mathrm{C}$ for $2 \mathrm{~h}$. Then, nitric acid was added to the solution very slowly and kept stirring at $95{ }^{\circ} \mathrm{C}$ for $6 \mathrm{~h}$. The obtained alumina sol was heated in a water bath at $80{ }^{\circ} \mathrm{C}$ for $2 \mathrm{~h}$ and cooled to room temperature. The resulting solid was dried in a vacuum oven at $80{ }^{\circ} \mathrm{C}$ for $24 \mathrm{~h}$ and then calcined in a muffle furnace at $500{ }^{\circ} \mathrm{C}$ for $4 \mathrm{~h}$. Al-HS was prepared by the following procedure. Typically, $45 \mathrm{~g}$ of Al $\left(\mathrm{NO}_{3}\right)_{3} \cdot 9 \mathrm{H}_{2} \mathrm{O}$ was dissolved in $250 \mathrm{~mL}$ of deionized water and then was mixed with $20 \mathrm{wt} \%$ TEAOH solution (tetraethyl ammonium hydroxide) under rigorous stirring till $\mathrm{pH}$ reached 5.0. The mixture was continuously stirred for $30 \mathrm{~min}$ before transferring into an autoclave equipped with a Teflon-liner. The hydrothermal treatment was conducted at $170{ }^{\circ} \mathrm{C}$ for $72 \mathrm{~h}$. The as-prepared sample was calcined at $500{ }^{\circ} \mathrm{C}$ for $5 \mathrm{~h}$ with a heating rate of $5{ }^{\circ} \mathrm{C} / \mathrm{min}$.

Fe-promoted Rh-based catalysts supported on the different $\mathrm{Al}_{2} \mathrm{O}_{3}$ samples were prepared by incipient wetness method. Before impregnation, $\mathrm{Al}_{2} \mathrm{O}_{3}$ samples were ground and sieved to 40-60 mesh. Aqueous solution of $\mathrm{Rh}\left(\mathrm{NO}_{3}\right)_{3} \cdot 2 \mathrm{H}_{2} \mathrm{O}(9.35 \mathrm{wt} \% \mathrm{Rh}$, Helishi) and $\mathrm{Fe}$ $\left(\mathrm{NO}_{3}\right)_{2} \cdot 6 \mathrm{H}_{2} \mathrm{O}$ were added dropwise to the given weight of support. The samples were kept stirring for $2 \mathrm{~h}$ and then dried at $110{ }^{\circ} \mathrm{C}$ for $12 \mathrm{~h}$. Finally, the samples were calcined at $500{ }^{\circ} \mathrm{C}$ for $4 \mathrm{~h}$. The nominal loading of $\mathrm{Rh}$ is 2 $\mathrm{wt} \%$ and $\mathrm{Fe} 4 \mathrm{wt} \%$ for all the catalysts. The catalysts supported on Al-CM, Al-SG, Al-CP and Al-HS were named as $\mathrm{RhFe} / \mathrm{Al}-\mathrm{CM}, \mathrm{RhFe} / \mathrm{Al}-\mathrm{SG}, \mathrm{RhFe} / \mathrm{Al}-\mathrm{CP}$ and $\mathrm{RhFe} /$ $\mathrm{Al}-\mathrm{HS}$, respectively.

\section{Characterization}

The $\mathrm{N}_{2}$ adsorption-desorption isotherms for alumina samples and the corresponding catalysts were measured in a Micromeritics ASAP 2000 equipment. XRD patterns were recorded on a diffractometer operating with $\mathrm{Cu} \mathrm{Ka}$ radiation at $40 \mathrm{kV}$. The power diffractograms of the samples were collected from 10 to $80^{\circ}$ at a rate of $6^{\circ} / \mathrm{min}$. $\mathrm{H}_{2} /$ CO chemisorption and TPR/ TPD experiments were carried out on a Micromeritics Autochem 2920 apparatus. The $\mathrm{H}_{2}$-TPR profile was recorded with a TCD detector according to $\mathrm{H}_{2}$ consumption during sample was reduced from room temperature to $800{ }^{\circ} \mathrm{C}$ ramped at a rate of $10{ }^{\circ} \mathrm{C} / \mathrm{min}$ under a $10 \% \mathrm{H}_{2} / \mathrm{Ar}(\mathrm{v} / \mathrm{v})$ flow. For $\mathrm{H}_{2}$-TPD experiments, typically, $200 \mathrm{mg}$ of sample was placed in a U-shaped quartz tube and pre-reduced in $50 \mathrm{~mL} / \mathrm{min}$ of $10 \% \mathrm{H}_{2} / \mathrm{Ar}(\mathrm{v} / \mathrm{v})$ flow at $350{ }^{\circ} \mathrm{C}$ for $2 \mathrm{~h}$, and then switched to He flow for $30 \mathrm{~min}$. After that, $\mathrm{H}_{2}$ was introduced into catalyst bed until saturation, and purged again by $\mathrm{He}$ for $30 \mathrm{~min}$. Finally, the sample was heated up to $800{ }^{\circ} \mathrm{C}$ under $\mathrm{He}$ atmosphere at a rate of $10^{\circ} \mathrm{C} / \mathrm{min}$, while the desorbed products were detected with a TCD detector. XPS experiments were performed using a Physical Electronics Quantum 2000 Scanning ESCA Microprobe. STEM measurements were performed on a Tecnai G2 F30 S-TWIN electron microscope with $300 \mathrm{kV}$ accelerating voltage via high-angle annular dark-field (HAADF). Point energy-dispersive X-ray spectroscopy (EDS) was taken in an area within $5 \mathrm{~nm}$ diameter. DRIFTS was carried out with a Nicolet 6700 spectrometer equipped with infrared cell (PIKE). The DRIFTS experiments contain $\mathrm{CO}$ adsorption, $\mathrm{CO}$ temperature-programmed surface reduction (CO-TPSR) and determination of surface hydroxyl group. For $\mathrm{CO}$ adsorption, first, the sample was reduced under pure $\mathrm{H}_{2}$ flow at $350{ }^{\circ} \mathrm{C}$ for $2 \mathrm{~h}$. After flushed by $\mathrm{N}_{2}$ for $30 \mathrm{~min}$, the sample was degassed under vacuum until that $10^{-4}$ mbar was achieved, and then background spectra were collected at designated temperature. Second, a flow of $5 \% \mathrm{CO} / \mathrm{He}(\mathrm{v} / \mathrm{v})$ was introduced to reduced catalysts for $30 \mathrm{~min}$. Finally, the IR spectra were recorded after flushed by $\mathrm{N}_{2}$ for $30 \mathrm{~min}$. For CO-TPSR, the IR spectra were recorded under $10 \% \mathrm{H}_{2} / \mathrm{Ar}(\mathrm{v} / \mathrm{v})$ flow with the temperate linearly increased from 30 to $260{ }^{\circ} \mathrm{C}$ after $\mathrm{CO}$ adsorption. For the determination of surface hydroxyl group, the sample was flushed by $\mathrm{N}_{2}$ at $300{ }^{\circ} \mathrm{C}$ and then degassed under $10^{-4}$ mbar vacuum for $2 \mathrm{~h}$. The 
IR spectra were collected at room temperature in the range of $3200-4000 \mathrm{~cm}^{-1}$.

\section{Catalytic reaction}

Reaction was carried out in a stainless fixed bed reactor with an inner diameter of $10 \mathrm{~mm} .1 .0 \mathrm{~g}$ catalyst $(1.3 \mathrm{~mL})$ was diluted with quartz sand $(4.2 \mathrm{~mL})$ and then placed in the middle of the reactor. The catalyst was heated to $350{ }^{\circ} \mathrm{C}$ and reduced in $\mathrm{H}_{2}$ at a flow rate of $60 \mathrm{~mL} / \mathrm{min}$ for $10 \mathrm{~h}$, then cooled down to the reaction temperature $\left(260{ }^{\circ} \mathrm{C}\right)$ in $\mathrm{H}_{2}$ flow. Subsequently, $60 \mathrm{~mL} / \mathrm{min}$ syngas $\left(\mathrm{H}_{2} / \mathrm{CO}=2\right)$ was introduced to reactor and kept at a pressure of $2 \mathrm{MPa}$. The flow rates of gas were controlled by a Brooks 5050 mass flowmeter. The effluent gas from the reactor was passed through a hot trap and a cold trap successively to separate gaseous and liquid products. A $24 \mathrm{~h}$ liquid sample was collected after steady state was achieved. Outlet gases and liquid sample were detected with two chromatographs (Agilent GC7890A), one is equipped with two TCD to analyze CO, $\mathrm{CO}_{2}, \mathrm{~N}_{2}$ and $\mathrm{H}_{2}$ using a 5-A molecular sieve column online and the other fitted with one FID and TCD to separate $\mathrm{C}_{1}-\mathrm{C}_{6}$ hydrocarbons, oxygenates and water using Plot $\mathrm{Q}$ column offline.

\section{Results and discussion}

\section{Characterization of support}

Figure 1 shows the $\mathrm{N}_{2}$ adsorption isotherms of the four $\mathrm{Al}_{2} \mathrm{O}_{3}$ samples. The type IV of isotherms and the existence

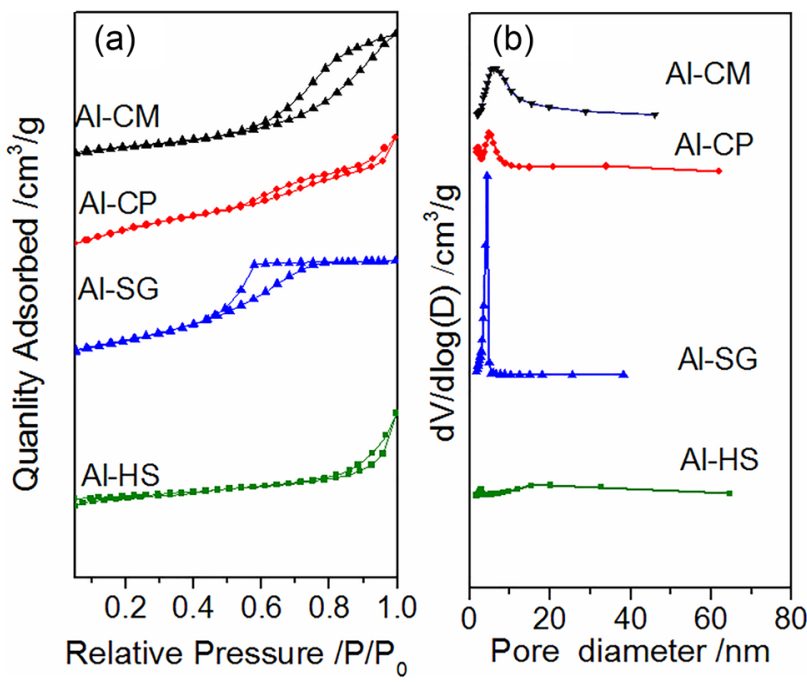

Fig. 1 Nitrogen adsorption isotherms and pore distribution for different alumina samples. a Nitrogen adsorption isotherms; b pore distribution of hysteresis loop indicate all the samples are mesopore structure. The type of hysteresis loop for Al-CM, Al-CP, Al-SG, Al-HS is attributed to $\mathrm{H} 4, \mathrm{H} 4, \mathrm{H} 2$ and $\mathrm{H} 3$, respectively. It is well known that the type of hysteresis loop is related with the special pore structure [14]. For instance, the presence of $\mathrm{H} 3$ hysteresis loop for Al-HS sample indicates the slit pore formed by the fibrous or sheet particle. Table 1 showed the textural properties of the different samples. Obviously, the surface areas of the samples are as follows: Al-CP (398) > Al-SG (336) > Al-CM (256) > Al-HS (90). Among the four alumina samples, Al-HS presents the lowest specific surface area. The enlarging pore effect, as a result of hydrothermal treatment, may be responsible for its low specific surface area.

Figure $2 \mathrm{a}$ presents the XRD profiles of the four $\mathrm{Al}_{2} \mathrm{O}_{3}$ samples. Typical characteristic peaks of $\gamma-\mathrm{Al}_{2} \mathrm{O}_{3}$ were observed for all the samples. However, besides $\gamma-\mathrm{Al}_{2} \mathrm{O}_{3}$, characteristic peaks of $\alpha-\mathrm{Al}_{2} \mathrm{O}_{3}, \mathrm{Al}_{2} \mathrm{O}_{3}$ for Al-HS were observed in Fig. 2b. The results indicate that Al-HS is constituted of mixed crystal phases, while Al-CM, Al-CP and $\mathrm{Al}-\mathrm{SG}$ are mainly consistent with the $\gamma-\mathrm{Al}_{2} \mathrm{O}_{3}$ crystal phase. In general, alumina with different forms presents different specific surface areas with the order of $\alpha-\mathrm{Al}_{2} \mathrm{O}_{3}<<\gamma-\mathrm{Al}_{2} \mathrm{O}_{3}$ [15], which can be responsible for the lowest specific area of Al-HS material.

\section{Characterization of catalysts}

The $\mathrm{H}_{2}$-TPR profiles of the four catalysts were presented in Fig. 3. It can be observed two peaks of $\mathrm{H}_{2}$ consumptions in Fig. 3, namely, one low temperature reduction peak (peak I) located at $50-300{ }^{\circ} \mathrm{C}$ and one high temperature board peak (peak II) in the range of $350-550{ }^{\circ} \mathrm{C}$. According to the literature [18], the peak II was ascribed to the reduction of $\mathrm{Fe}_{2} \mathrm{O}_{3}$ to $\mathrm{Fe}_{3} \mathrm{O}_{4}$ and $\mathrm{Fe}_{3} \mathrm{O}_{4}$ to $\mathrm{Fe}$ speices.

The theoretical and calculated $\mathrm{H}_{2}$ consumptions of Fepromoted $\mathrm{Rh}$-based catalysts are listed in Table 2 . Therefore, the peak I should be ascribed to the co-reduction of $\mathrm{Rh}_{2} \mathrm{O}_{3}$ and $\mathrm{Fe}_{2} \mathrm{O}_{3}$ species. The area of peak $\mathrm{I}$ is in order of $\mathrm{RhFe} /$ Al-HS $>$ RhFe/Al-CM $>$ RhFe/Al-SG $>$ RhFe/Al-CP. Distinctly, the RhFe/Al-HS catalyst exhibits the highest reduction degree and RhFe/Al-CM less. In addition, for RhFe/

Table 1 Textural properties of different type of $\mathrm{Al}_{2} \mathrm{O}_{3}$

\begin{tabular}{llll}
\hline Samples & $\begin{array}{l}\text { BET surface area } \\
\left(\mathrm{m}^{2} \mathrm{~g}^{-1}\right)\end{array}$ & $\begin{array}{l}\text { Pore volume }\left(\mathrm{cm}^{3}\right. \\
\left.\mathrm{g}^{-1}\right)\end{array}$ & $\begin{array}{l}\text { Pore } \\
\text { diameter } \\
(\mathrm{nm})\end{array}$ \\
\hline Al-CM & 256 & 0.46 & 9.0 \\
Al-CP & 398 & 0.48 & 4.9 \\
Al-SG & 336 & 0.43 & 5.0 \\
Al-HS & 90 & 0.33 & 14.6 \\
\hline
\end{tabular}



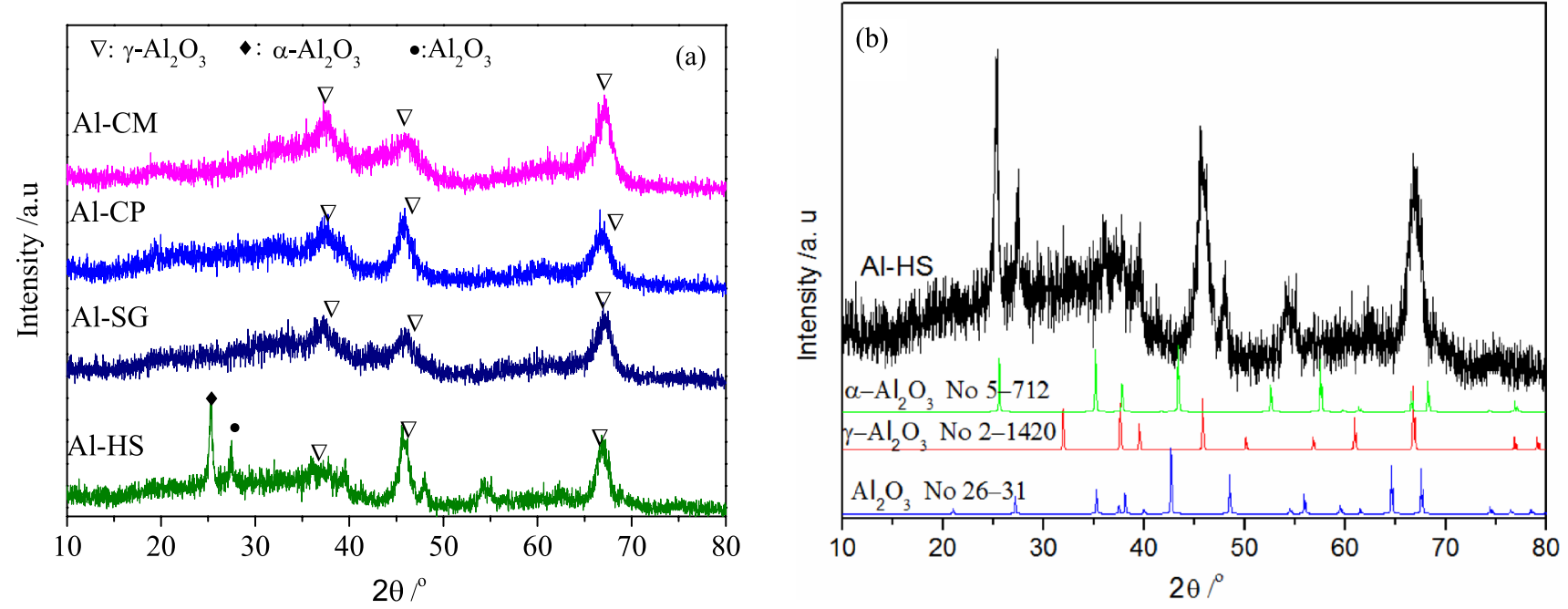

Fig. 2 XRD profiles of different alumina samples

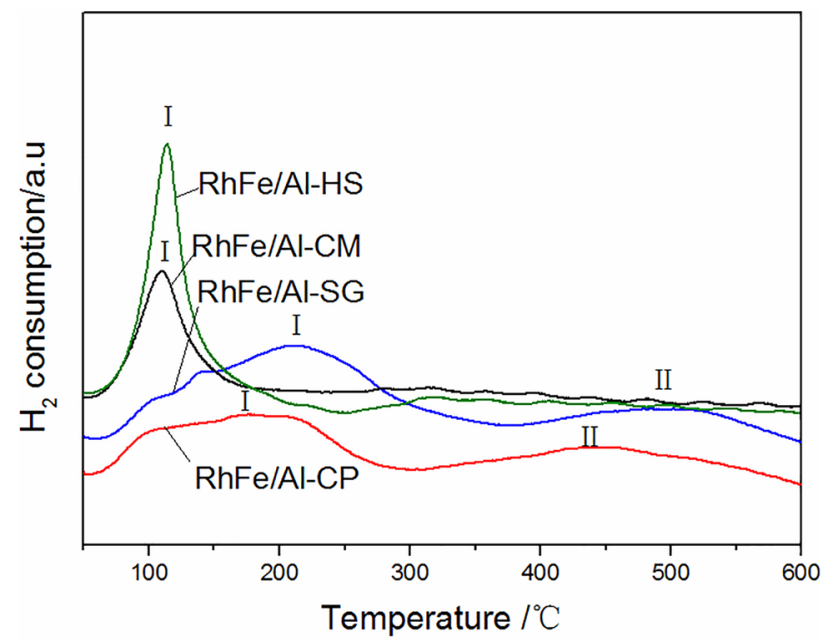

the interaction between metal and support got weaker and the contact between $\mathrm{Rh}$ and Fe was enhanced for the above two catalysts. Considering with the activity data, the catalysts owning stronger $\mathrm{Rh}-\mathrm{Fe}$ interaction correspond to the higher ethanol selectivity, which indicates that the weaker interaction between $\mathrm{Rh}$ and $\mathrm{Al}$ may be conductive to the formation of ethanol.

The $\mathrm{H}_{2}$-TPD profiles of catalysts are presented in Fig. 4 . As can be seen, two peaks were presented on all the samples. The peaks at lower temperature $\left(50-200{ }^{\circ} \mathrm{C}\right)$ and higher temperature $\left(300-500{ }^{\circ} \mathrm{C}\right.$ ) are denoted as $\mathrm{H}_{\alpha}$ and $\mathrm{H}_{\beta}$, respectively. $\mathrm{H}_{\alpha}$ is ascribed to the weak adsorption of hydrogen and $\mathrm{H}_{\beta}$ the strong adsorption of it. It is accepted that $\mathrm{H}_{\beta}$ is responsible for the hydrogenation ability of Rh-based catalysts [16]. Obviously, RhFe/Al-HS exhibits higher peak area and higher temperature of $\mathrm{H}_{\beta}$ compared with the other catalysts. This indicates that the RhFe/Al-HS has stronger ability to activate hydrogen, which is helpful for promoting the catalytic activity.

Since metal particles cannot be easily distinguished from Al-HS and $\mathrm{RhFe} / \mathrm{Al}-\mathrm{CM}$ catalysts, the reduction temperature alumina, dark-field imaging technique (HAADF) was used to observe surface metal particle morphology of catalysts corresponding un-promoted ones. It can be concluded that

Table $2 \mathrm{H}_{2}$ consumption of catalysts

\begin{tabular}{llllll}
\hline Catalysts & $\begin{array}{l}\text { Reduction } \\
\text { peak }\left({ }^{\circ} \mathrm{C}\right)\end{array}$ & $\begin{array}{l}\text { Calculated and } \\
\text { theoretical }{ }^{\mathrm{b}} \mathrm{H}_{2} \text { consump- } \\
\text { tion }(\mathrm{mmol})\end{array}$ & Catalysts & $\begin{array}{l}\text { Reduction } \\
\text { peak }\left({ }^{\circ} \mathrm{C}\right)\end{array}$ & $\begin{array}{l}\text { Calculated and } \\
\text { theoretical }{ }^{\mathrm{b}} \mathrm{H}_{2} \text { consump- } \\
\text { tion }(\mathrm{mmol})\end{array}$ \\
\hline $\mathrm{RhFe} / \mathrm{Al}-\mathrm{CM}$ & 111 & $40^{\mathrm{a}}\left(249^{\mathrm{b}}\right)$ & $\mathrm{Rh} / \mathrm{Al}-\mathrm{CM}$ & 120 & $36^{\mathrm{a}}\left(58^{\mathrm{b}}\right)$ \\
$\mathrm{RhFe} / \mathrm{Al}-\mathrm{CP}$ & 167 & $37^{\mathrm{a}}\left(249^{\mathrm{b}}\right)$ & $\mathrm{Rh} / \mathrm{Al}-\mathrm{CP}$ & 131 & $22^{\mathrm{a}}\left(58^{\mathrm{b}}\right)$ \\
$\mathrm{RhFe} / \mathrm{Al}-\mathrm{SG}$ & 210 & $35^{\mathrm{a}}\left(249^{\mathrm{b}}\right)$ & $\mathrm{Rh} / \mathrm{Al}-\mathrm{SG}$ & 160 & $30^{\mathrm{a}}\left(58^{\mathrm{b}}\right)$ \\
$\mathrm{RhFe} / \mathrm{Al}-\mathrm{HS}$ & 114 & $53^{\mathrm{a}}\left(249^{\mathrm{b}}\right)$ & $\mathrm{Rh} / \mathrm{Al}-\mathrm{HS}$ & 132 & $48^{\mathrm{a}}\left(58^{\mathrm{b}}\right)$ \\
\hline
\end{tabular}

${ }^{\mathrm{a}} \mathrm{H}_{2}$ consumption was calculated with $50 \mathrm{mg} \mathrm{CuO}$ as external reference

${ }^{\mathrm{b}}$ Sample weight, $200 \mathrm{mg}$ 


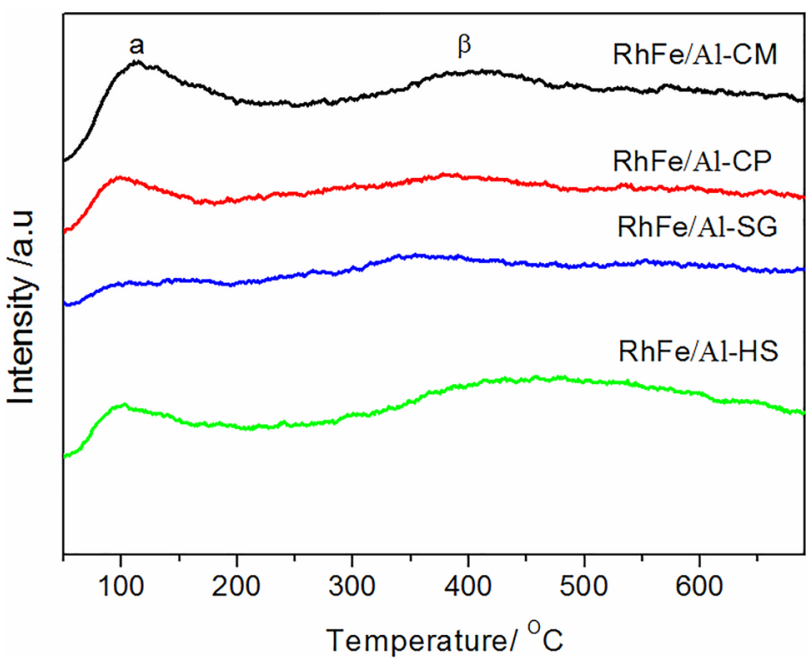

Fig. $4 \mathrm{H}_{2}$-TPD profiles of Rh-based catalysts supported on different type of $\mathrm{Al}_{2} \mathrm{O}_{3}$

after reduction. Figure 5 shows STEM images of catalysts. From STEM images (Fig. 5A, D) of the RhFe/Al-CM and $\mathrm{RhFe} / \mathrm{Al}-\mathrm{HS}$, it can be observed that the metal particle sizes of them are both in the range of 1-4 nm with the average diameter of 2.7 and $3.8 \mathrm{~nm}$, respectively. However, it can be seen from the images of RhFe/Al-SG (Fig. 5C) and RhFe/ $\mathrm{Al}-\mathrm{CP}$ (Fig. 5B) that the metal particle size is approximately about or less than $1 \mathrm{~nm}$. The favorable metal particle size for ethanol formation was reported to be 2-4 $\mathrm{nm}$ [17]. In our case, the metal particles less than $2 \mathrm{~nm}$ may form stronger interaction with alumina support leading to decreased reducible species according to the TPR results. Figure 6 shows the corresponding EDS spectra of catalysts, in which one point within the metal particle region (P1) and the other metal particle-free region (P2) was selected at random. There exists Rh and Fe signal in the EDS spectra of P1 for all the samples, indicating $\mathrm{Rh}$ and Fe are in close contact. However, only $\mathrm{Fe}$ signal was observed in the EDS spectra of $\mathrm{P} 2$ for RhFe/Al-CP, RhFe/Al-SG and RhFe/Al-CM samples, which means some single Fe species distribute on the surface of these catalysts. Exceptionally, on RhFe/ Al-HS catalyst, there is a weak signal of Rh and Fe within metal particle-free region on the EDS spectrum, indicating that more $\mathrm{Fe}$ and $\mathrm{Rh}$ species are in intimate contact on the surface of support.

To get the information of $\mathrm{Rh}$ dispersion of catalysts more accurately, $\mathrm{CO}$ and $\mathrm{H}_{2}$ chemisorption experiments in a pulse mode were both carried out. Tables 3 and 4 show the results of the chemisorption of $\mathrm{CO}$ and $\mathrm{H}_{2}$, respectively. The results summarized in Tables 3 and 4 show that $\mathrm{Rh}$ dispersion calculated by the $\mathrm{H}_{2}$ chemisorption is higher than the $\mathrm{CO}$ chemisorption. Despite this, the same trend about Rh dispersion can be gotten. Namely, RhFe/Al-HS has a higher $\mathrm{Rh}$ dispersion while $\mathrm{RhFe} / \mathrm{Al}-\mathrm{CP}$ and $\mathrm{RhFe} /$ Al-SG shows a lower dispersion compared with $\mathrm{RhFe} /$ Al-CM. However, RhFe/Al-CP and RhFe/Al-SG should have higher Rh dispersion according to STEM results. The possible reason for the inconsistent results given by chemisorption and STEM may be due to that the smaller $\mathrm{Rh}$ particles enhanced the interaction with alumina support, resulting in a part of $\mathrm{Rh}$ particles incorporation into the alumina skeleton.

XPS spectra of fresh catalysts were shown in Fig. 7. The XPS intensity ratios and binding energies (BEs) of Rh $3 \mathrm{~d}$ and $\mathrm{Fe} 2 \mathrm{p}$ was presented in Table 5 . The surface atom concentrations of $\mathrm{Rh} / \mathrm{Al}$ are in the order of $\mathrm{RhFe} / \mathrm{Al}-\mathrm{HS}>\mathrm{RhFe} /$ $\mathrm{Al}-\mathrm{CM}>\mathrm{RhFe} / \mathrm{Al}-\mathrm{CP}>\mathrm{RhFe} / \mathrm{Al}-\mathrm{SG}$. The ratio of $\mathrm{Rh} / \mathrm{Fe}$ for $\mathrm{RhFe} / \mathrm{Al}-\mathrm{HS}$ is 0.28 , which is even higher than the expected value $(0.27)$. The above indicated that more rhodium species enrichment on the surface of RhFe/Al-HS. In addition, the binding energy of $\mathrm{Rh} 3 \mathrm{~d}_{5 / 2}$ and $\mathrm{Fe} 2 \mathrm{p}_{3 / 2}$ of RhFe/Al-HS exhibits obvious shift compared to the other catalysts. This further proved stronger interaction exists between $\mathrm{Rh}$ and Fe for this catalyst.

The interaction between highly dispersed active metal and support for different $\mathrm{Al}_{2} \mathrm{O}_{3}$-supported catalysts varies greatly from the above analysis. Surface hydroxyls of catalysts may be one possible reason for this interaction. Figure 8 presents the surface hydroxyl group of catalyst and supports. The hydroxyl groups on the surface of alumina were classified into I, II, and III, in which type I > type II $>$ type III in order of frequencies of them [15]. As shown in Fig. 8, the bands at 3723 (I), 3687 (II), $3572 \mathrm{~cm}^{-1}$ (II or III) are ascribed to the absorption of isolated - $\mathrm{OH}$ groups, weakly $\mathrm{H}$-bonded and strongly $\mathrm{H}$-bonded $\mathrm{OH}$ groups, respectively [18]. It can be seen from Fig. 8a that the intensity of hydroxyl groups for alumina samples is in order of Al-SG $>$ Al-CP $>$ Al-CM $>$ Al-HS. The corresponding catalysts also show the same order as can be seen in Fig. 8b. Some researchers believed $\mathrm{CO}_{2}$ comes from the reaction of strongly adsorbed $\mathrm{CO}$ species with hydroxyl groups of $\mathrm{Al}_{2} \mathrm{O}_{3}$ support [20]. This is in accordance with our experiments results that $\mathrm{RhFe} / \mathrm{Al}-\mathrm{SG}$ shows the highest $\mathrm{CO}_{2}$ selectivity with the most amount of surface hydroxyl group. However it may be, there is no doubt that the metal-support interaction increases with the increasing amount of hydroxyl group. Moreover, it can be observed from Fig. 8b that the ratio of different type of hydroxyl groups for $\mathrm{RhFe} / \mathrm{Al}-\mathrm{CP}$ and $\mathrm{RhFe} /$ Al-SG catalyst is similar with that of RhFe/Al-CM. However, the proportion of type I (isolated hydroxyl) increases for RhFe/Al-HS.

The infrared spectra of the catalysts after $\mathrm{CO}$ adsorption at $30{ }^{\circ} \mathrm{C}$ are shown in Fig. 9. The $2055 \mathrm{~m}^{-1}$ band can be ascribed to linear adsorbed $\mathrm{CO}(\mathrm{CO}(\mathrm{l})$ ) and double band at 2084 and $2017 \mathrm{~cm}^{-1}$ can be assigned to the symmetric and asymmetric carbonyl stretching of the dicarbonyl 

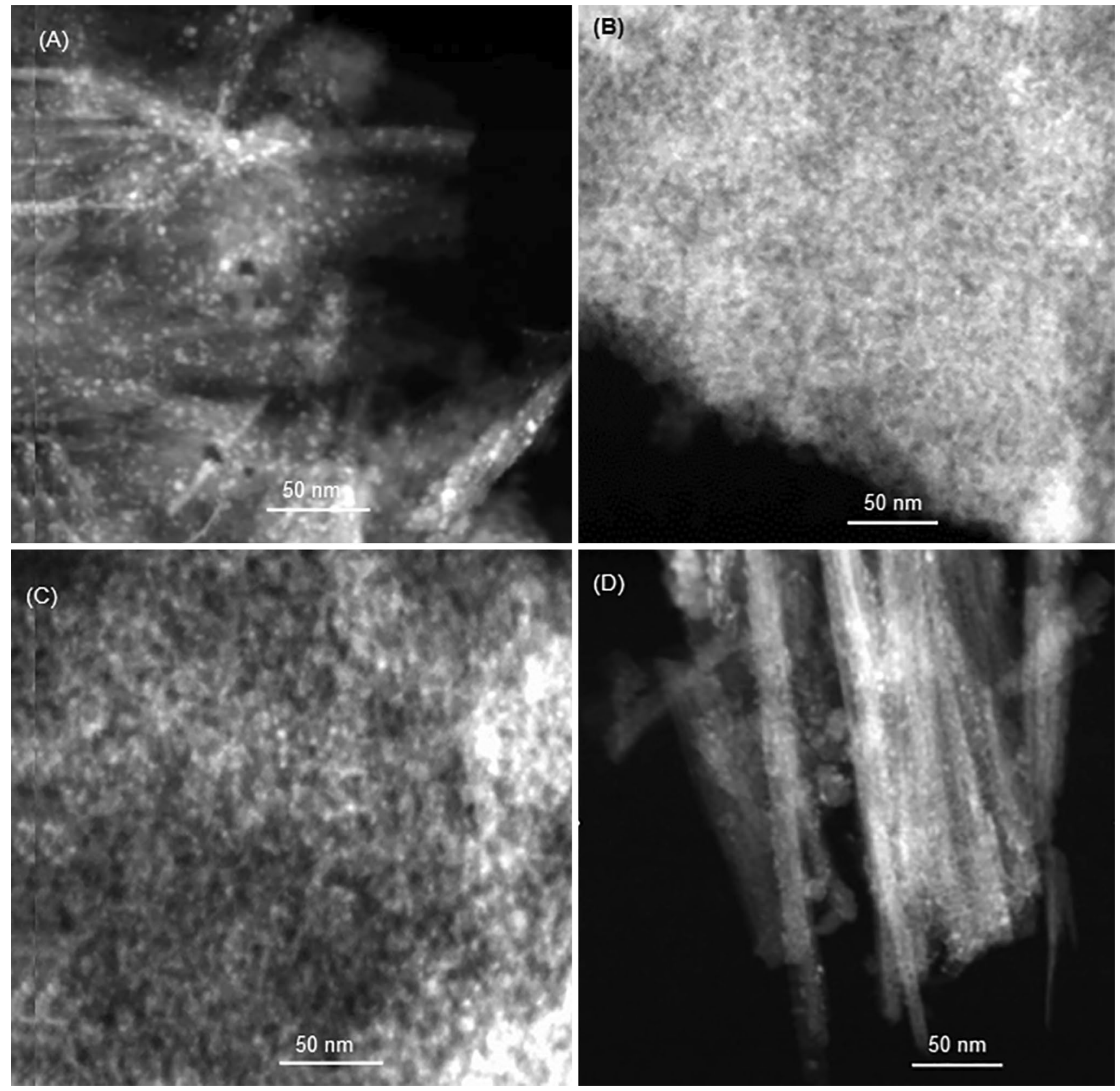

Fig. 5 STEM images of Rh-based catalysts supported on different type of $\mathrm{Al}_{2} \mathrm{O}_{3}$. A RhFe/Al-CM; B RhFe/Al-CP; C RhFe/Al-SG; D RhFe/ Al-HS

$\mathrm{Rh}^{+}(\mathrm{CO})_{2}(\mathrm{CO}(\mathrm{gem}))$ [19]. The board band centered at $1860 \mathrm{~cm}^{-1}$ is assigned to bridge bonded $\mathrm{CO}(\mathrm{CO}(\mathrm{b}))$, whose intensity was found to be related with the selectivity of $\mathrm{CH}_{4}$ [10]. It is widely accepted that $\mathrm{CO}$ (gem) is formed on $\mathrm{Rh}^{+}$, which is favorable for $\mathrm{CO}$ insertion, while $\mathrm{CO}$ (l) and $\mathrm{CO}(\mathrm{b})$ formed on $\mathrm{Rh}^{0}$, which is helpful for $\mathrm{CO}$ dissociation [20]. It can be seen from Fig. 9 that the intensity of $\mathrm{CO}$ (gem) is in the order of RhFe/Al-HS $>\mathrm{RhFe} /$ $\mathrm{Al}-\mathrm{CM}>\mathrm{RhFe} / \mathrm{Al}-\mathrm{CP}>\mathrm{RhFe} / \mathrm{Al}-\mathrm{SG}$, which means that $\mathrm{RhFe} / \mathrm{Al}-\mathrm{HS}$ has more $\mathrm{Rh}^{+}$center. It was reported that isolated hydroxyl groups is favorable to transfer $\mathrm{Rh}^{0}$ into $\mathrm{Rh}^{+}$[21]. Therefore, we presume that more abundant isolated hydroxyl groups are responsible for more $\mathrm{Rh}^{+}$ on $\mathrm{RhFe} / \mathrm{Al}-\mathrm{HS}$. Moreover, the bridged adsorbed $\mathrm{CO}$ is strongest on the $\mathrm{RhFe} / \mathrm{Al}-\mathrm{HS}$ catalyst, which is consistent with the activity data for methane selectivity of this catalyst (see Table 6).

To know the dissociation ability and hydrogenation rate of the catalyst, CO-TPSR was carried out. As shown in Fig. 10, the band at $3015 \mathrm{~cm}^{-1}$ is ascribed to the stretching 

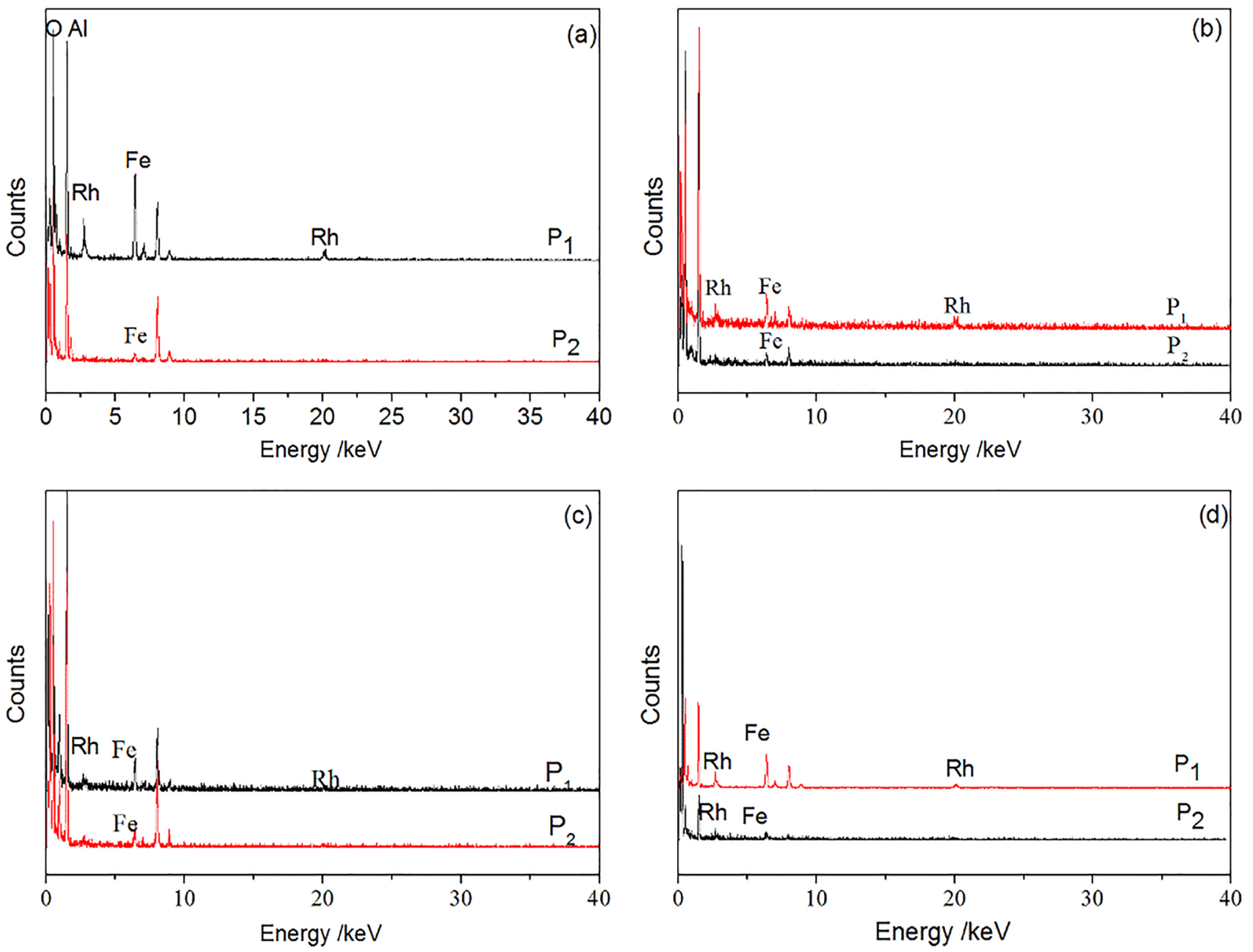

Fig. 6 EDS profiles of Rh-based catalysts supported on different type of $\mathrm{Al}_{2} \mathrm{O}_{3}$. a RhFe/Al-CM; $\mathbf{b}$ RhFe/Al-CP; $\mathbf{c}$ RhFe/Al-SG; d RhFe/Al-HS

Table 3 CO chemisorption results of catalysts

\begin{tabular}{lcl}
\hline Catalysts & CO-chemisorbed/ $\mu \mathrm{mol} \mathrm{g}^{-1}$ & $\begin{array}{l}\text { Metal dis- } \\
\text { persion/\% }\end{array}$ \\
\hline RhFe/Al-CM & 71.2 & 36.6 \\
RhFe/Al-CP & 64.6 & 32.7 \\
RhFe/Al-SG & 43.1 & 22.2 \\
RhFe/Al-HS & 116.6 & 58.6 \\
\hline
\end{tabular}

Table $4 \quad \mathrm{H}_{2}$ chemisorption results of catalysts

\begin{tabular}{lcl}
\hline Catalysts & $\mathrm{H}_{2}$-chemisorbed $/ \mu \mathrm{mol} \mathrm{g} \mathrm{g}^{-1}$ & $\begin{array}{l}\text { Metal } \\
\text { dispersion } \\
1 \%\end{array}$ \\
\hline $\mathrm{RhFe} / \mathrm{Al}-\mathrm{CM}$ & 92.3 & 47.4 \\
$\mathrm{RhFe} / \mathrm{Al}-\mathrm{CP}$ & 89.6 & 40.1 \\
$\mathrm{RhFe} / \mathrm{Al}-\mathrm{SG}$ & 85.2 & 35.1 \\
$\mathrm{RhFe} / \mathrm{Al}-\mathrm{HS}$ & 160.8 & 82.7 \\
\hline
\end{tabular}

vibration of gaseous methane, which intensity can be used as a tool to measure $\mathrm{CO}$ dissociation ability of catalyst [22]. The formation of methane for RhFe/Al-CM, RhFe/ Al-CP, RhFe/Al-SG and RhFe/Al-HS appeared at $220^{\circ} \mathrm{C}$, $210{ }^{\circ} \mathrm{C}, 200{ }^{\circ} \mathrm{C}, 190{ }^{\circ} \mathrm{C}$, respectively, which means that $\mathrm{RhFe} / \mathrm{Al}-\mathrm{HS}$ possessed strongest $\mathrm{CO}$ dissociation ability, whereas the $\mathrm{RhFe} / \mathrm{Al}-\mathrm{CM}$ showed the weakest dissociation. In addition, it was observed from the spectra in the range of $1800-2200 \mathrm{~cm}^{-1}$ that the hydrogenation rate of adsorbed $\mathrm{CO}$ is as follows: RhFe/Al-SG $>\mathrm{RhFe} / \mathrm{Al}-\mathrm{CP}>\mathrm{RhFe} /$ Al-HS > RhFe/Al-CM.

Table 6 lists the activities data of the catalysts. These data were taken with $2: 1 \mathrm{H}_{2}: \mathrm{CO}$ mix at a total pressure $2 \mathrm{MPa}$ and a temperature of $260{ }^{\circ} \mathrm{C}$. The results show that product contains $\mathrm{CO}_{2}$, hydrocarbons, methanol, ethanol and other oxygenates. Among the by-products, $\mathrm{CO}_{2}, \mathrm{CH}_{4}$ and higher hydrocarbons should be inhibited more seriously due to higher separation cost and lower economic value. Among the four catalysts, RhFe/Al-HS shows the highest 

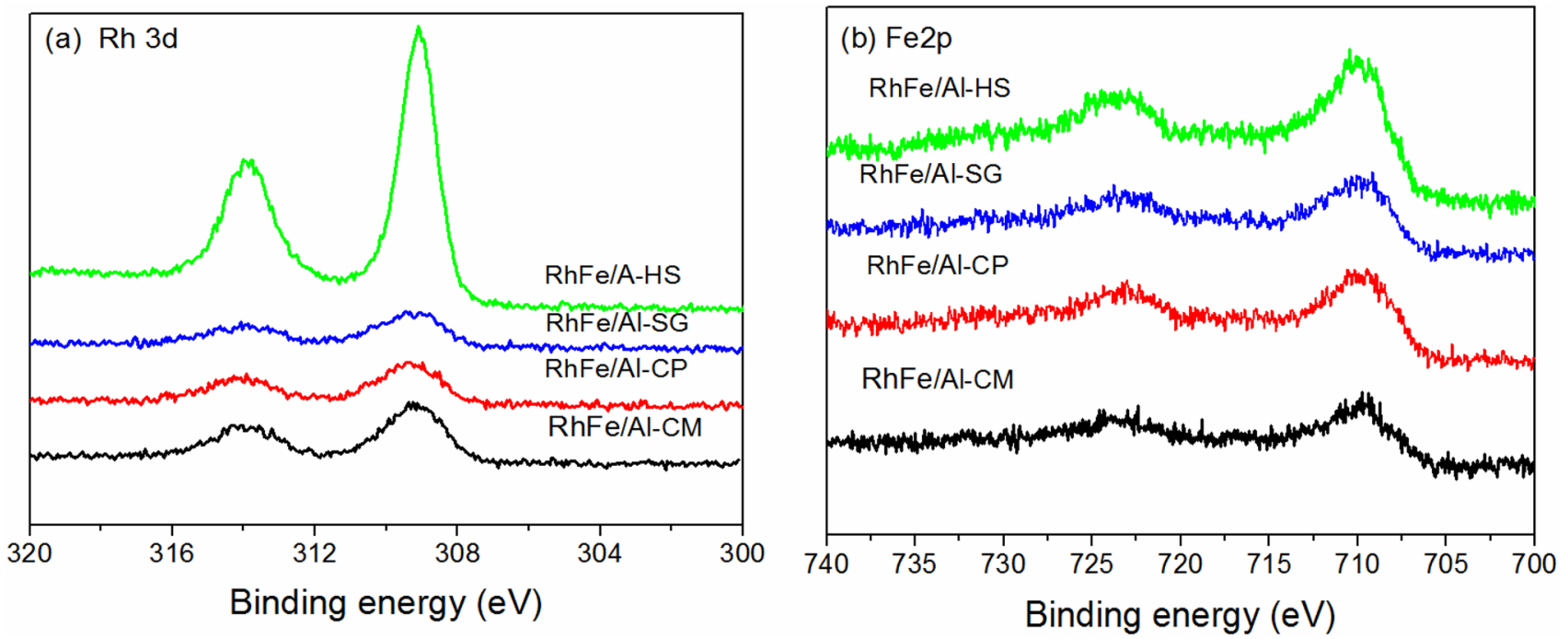

Fig. 7 XPS spectra of $\mathbf{a}$ Rh $3 d$ and $\mathbf{b}$ Fe $2 p$ for the catalysts

Table 5 Binding energy and surface composition of catalysts determined by XPS

\begin{tabular}{|c|c|c|c|c|c|}
\hline \multirow[t]{2}{*}{ Catalysts } & \multicolumn{2}{|c|}{ Atomic ratio from XPS } & \multirow[b]{2}{*}{$\mathrm{Rh} / \mathrm{Fe}^{\mathrm{a}}$} & \multicolumn{2}{|l|}{ Binding energy $(\mathrm{eV})$} \\
\hline & $\mathrm{Rh} / \mathrm{Al}$ & $\mathrm{Rh} / \mathrm{Fe}^{\mathrm{a}}$ & & $\mathrm{Rh} 3 \mathrm{~d}_{5 / 2}$ & $\mathrm{Fe} 2 \mathrm{p}_{3 / 2}$ \\
\hline RhFe/Al-GM & 0.79 & 0.24 & 0.27 & 309.3 & 710.4 \\
\hline RhFe/Al-CP & 0.74 & 0.22 & 0.27 & 309.4 & 710.4 \\
\hline RhFe/Al-SG & 0.64 & 0.19 & 0.27 & 309.4 & 710.4 \\
\hline RhFe/Al-HS & 1.21 & 0.28 & 0.27 & 309.5 & 710.8 \\
\hline
\end{tabular}

${ }^{\mathrm{a}}$ Atomic ratio of $\mathrm{Rh} / \mathrm{Fe}$ expected in the whole sample
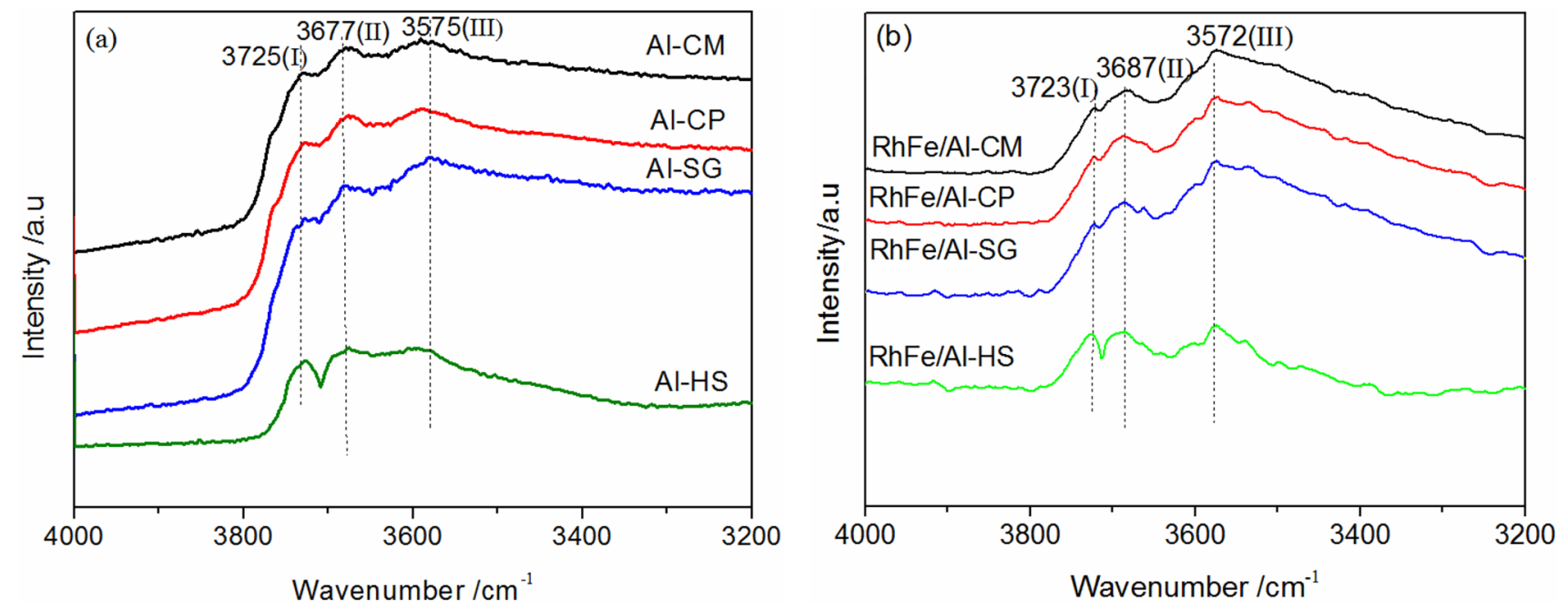

Fig. 8 Surface hydroxyl groups of different $\mathrm{Al}_{2} \mathrm{O}_{3}$ support and corresponding catalysts $\mathbf{a}$ support; $\mathbf{b}$ catalysts 


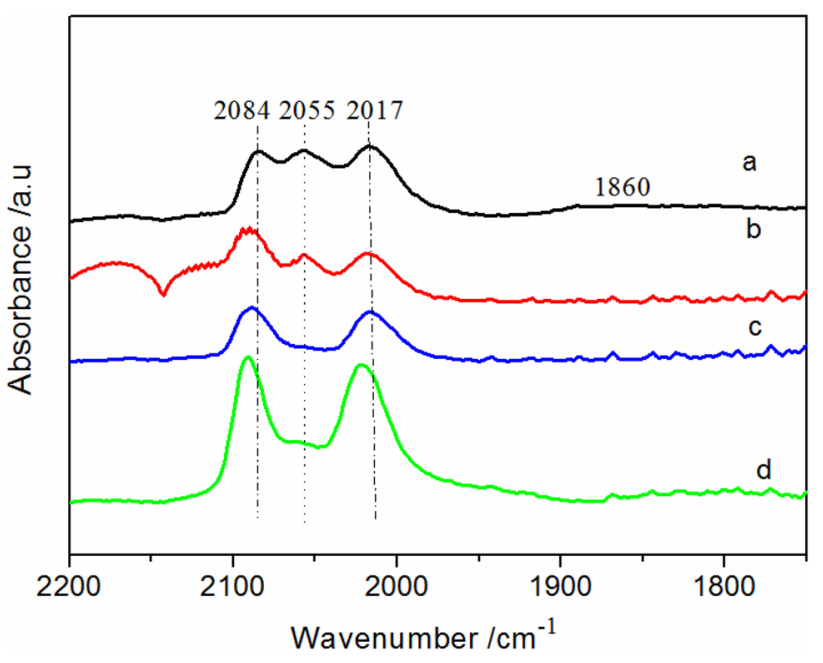

Fig. 9 FTIR spectra of adsorbed $\mathrm{CO}$ on different type of $\mathrm{Al}_{2} \mathrm{O}_{3}$-supported Rh-based catalysts. a $\mathrm{RhFe} / \mathrm{Al}-\mathrm{CM}$; b RhFe/Al-CP; c RhFe/Al-SG; d RhFe/Al-HS

ethanol selectivity $(\sim 24.6 \%)$ and the lowest $\mathrm{CO}_{2}$ selectivity $(\sim 8 \%)$, and also, $\mathrm{RhFe} / \mathrm{Al}-\mathrm{CM}$ exhibits higher ethanol selectivity with moderate $\mathrm{CO}$ conversion. It can be seen that $\mathrm{Al}-\mathrm{CP}$ - and Al-SG-supported RhFe catalysts exhibit higher CO conversion but only with $7.3 \%$ and $5.8 \%$ ethanol selectivity, respectively. In general, for $\mathrm{CO}$ conversion, $\mathrm{RhFe} /$ Al-SG $>$ RhFe/Al-CP $>$ RhFe/Al-CM $>$ RhFe/Al-HS. And for ethanol selectivity, $\mathrm{RhFe} / \mathrm{Al}-\mathrm{HS}>\mathrm{RhFe} / \mathrm{Al}-\mathrm{CM}>\mathrm{RhFe} /$ $\mathrm{Al}-\mathrm{SG}>\mathrm{RhFe} / \mathrm{Al}-\mathrm{CP}$.

It has been reported that $\left(\mathrm{Rh}_{\mathrm{x}}{ }^{0}-\mathrm{Rh}_{\mathrm{y}}{ }^{+}\right)-\mathrm{O}-\mathrm{Fe}^{3+}\left(\mathrm{Fe}^{2+}\right)$ is the active site for the formation of ethanol [23]. Therefore, the synergy effect between $\mathrm{Rh}$ and $\mathrm{Fe}$, the formation of $\mathrm{Rh}^{+}$would be beneficial to form the active site for ethanol synthesis.

The characterization and catalytic results show that the $\mathrm{Rh}-\mathrm{Fe}$ interactions are greatly affected by the support. The surface areas of the samples are as follows:
$\mathrm{Al}-\mathrm{CP}>\mathrm{Al}-\mathrm{SG}>\mathrm{Al}-\mathrm{CM}>\mathrm{Al}-\mathrm{HS}$. Among them, Al-HSsupported catalysts have the highest ethanol selectivity although with the lowest specific area, indicating the specific area of the catalysts was not in direct proportion to their catalytic performances. XRD showed the presence of mixed $\mathrm{Al}_{2} \mathrm{O}_{3}$ crystalline phases in the Al-HS support prepared by hydrothermal synthesis. Compared to the Al-CM carrier, the greater specific area for Al-CP and Al-SG supported catalyst may lead to too stronger interaction between meatal and support, which is not good for Rh-Fe interaction. Al-HS carrier with nano-fibrous morphology supported catalysts may weaken the interaction between metal and support, correspondingly, the contact between $\mathrm{Rh}$ and $\mathrm{Fe}$ is strengthened, which can also be proved by $\mathrm{H}_{2}$-TPR and EDS. The lower surface hydroxyl group intensity of Al-HS support may be responsible for the above interactions. The higher specific surface area Al-SG- and Al-CP-supported catalysts exhibited a higher $\mathrm{CO}$ conversion, but most of $\mathrm{CO}$ was converted into hydrocarbon and $\mathrm{CO}_{2}$. From the results of TPR, it can be inferred that there exists more single $\mathrm{Fe}$ species over the above two catalysts, which is favorable for hydrogenation and water gas shift reaction. On the other hand, some researchers believed $\mathrm{CO}_{2}$ comes from the reaction of strongly adsorbed $\mathrm{CO}$ species with hydroxyl groups of $\mathrm{Al}_{2} \mathrm{O}_{3}$ support [20, 24]. This is in accordance with our experiments results that $\mathrm{RhFe} / \mathrm{Al}-\mathrm{SG}$ has strongest hydroxyl group and shows the highest $\mathrm{CO}_{2}$ selectivity.

The formation of $\mathrm{Rh}^{+}$is also important for the formation of active sites. It is widely accepted that the dicarbonyl species can only be formed on highly dispersed rhodium [24]. $\mathrm{H}_{2}$ and $\mathrm{CO}$ chemisorptions showed that $\mathrm{Rh}$ dispersion was in order of $\mathrm{RhFe} / \mathrm{Al}-\mathrm{HS}>\mathrm{RhFe} / \mathrm{Al}-\mathrm{CM}>\mathrm{RhFe} / \mathrm{Al}-\mathrm{CP}>\mathrm{RhFe} /$ Al-SG. This indicated Al-HS-supported catalyst has a higher Rh dispersion than others, which also evidenced by XPS. On the other hand, DRIFTS of CO adsorption shows that RhFe/ Al-HS has more dicarbonyl species, which comes from $\mathrm{Rh}^{+}$ sites.
Table 6 CO hydrogenation over Rh-based catalysts supported on different type of $\mathrm{Al}_{2} \mathrm{O}_{3}$

\begin{tabular}{lllllrrr}
\hline Catalysts & $\mathrm{X}_{\mathrm{CO}} / \%$ & \multicolumn{7}{l}{ Product selectivity/C\% } \\
\cline { 3 - 8 } & & $\mathrm{CH}_{4}$ & $\mathrm{C}_{2+} \mathrm{HC}$ & $\mathrm{MeOH}$ & $\mathrm{EtOH}$ & $\mathrm{CO}_{2}$ & Others $^{\mathrm{b}}$ \\
\hline $\mathrm{RhFe} / \mathrm{Al}-\mathrm{CM}$ & 25.8 & 28.6 & 13.3 & 15.2 & 20.5 & 14.2 & 8.2 \\
$\mathrm{RhFe} / \mathrm{Al}-\mathrm{SG}$ & 38.6 & 24.1 & 23.9 & 5.7 & 7.3 & 29.1 & 9.9 \\
$\mathrm{RhFe} / \mathrm{Al}-\mathrm{CP}$ & 35.4 & 24.8 & 27.2 & 5.2 & 5.8 & 28.8 & 8.2 \\
$\mathrm{RhFe} / \mathrm{Al}-\mathrm{HS}$ & 13.6 & 29.1 & 10.1 & 19.4 & 24.6 & 8.0 & 8.7 \\
\hline
\end{tabular}

Catalyst: $1 \mathrm{~g}$; reaction conditions: $T=260^{\circ} \mathrm{C} P=2 \mathrm{MPa}, \mathrm{H}_{2} / \mathrm{CO}=2$, space velocity $=3600 \mathrm{~mL} /(\mathrm{h}$. gcat) aproduct selectivity $=n_{i} M_{\mathrm{i}} / \sum\left(n_{i} M_{i}\right)$, where $n_{i}$ and $M_{i}$ are the carbon atoms number and molar percent of product $i$, respectively

${ }^{\mathrm{b}}$ Oxygenates with two or more carbons except ethanol(acetaldehyde, acetone, $n$-propanol, $i$-propanol, $n$-butanol, $i$-butanol and $n$-pentanol 

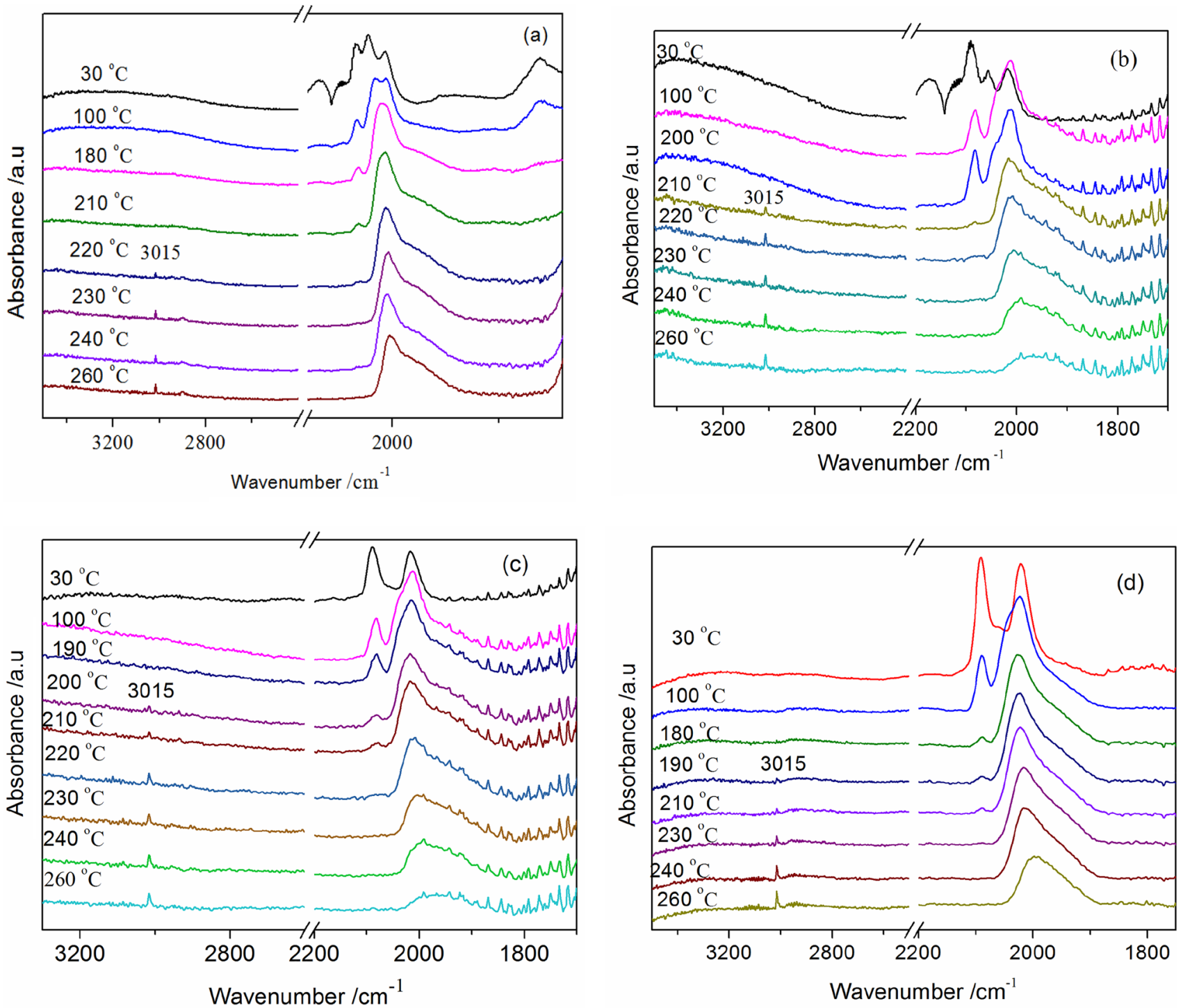

Fig. 10 DRIFTS spectra of CO-TPSR on different type of $\mathrm{Al}_{2} \mathrm{O}_{3}$-supported Rh-based catalysts. a mRhFe/Al-CM; b RhFe/Al-CP; $\mathbf{c}$ RhFe/Al-SG; d RhFe/Al-HS

According to widely accepted mechanism for ethanol synthesis (see Fig. 11), a good Rh-based catalyst should balance the ability of $\mathrm{CO}$ dissociation, $\mathrm{CO}$ insertion and $\mathrm{CO}$ hydrogenation. DRIFTS study indicates that RhFe/Al-HS have stronger $\mathrm{CO}$ dissociation capacity, moderate $\mathrm{CO}$ hydrogenation rate and more $\mathrm{Rh}^{+}$sites for $\mathrm{CO}$ insertion. Therefore, stronger $\mathrm{CO}$ dissociation capacity, moderate $\mathrm{CO}$ hydrogenation rate and stronger $\mathrm{CO}$ insertion may be responsible for the good performance of $\mathrm{RhFe} / \mathrm{Al}-\mathrm{HS}$.

\section{Conclusion}

Four kinds of alumina were used as supports of $\mathrm{Fe}$ promoted Rh-based catalysts. The ethanol selectivity of $\mathrm{RhFe} / \mathrm{Al}-\mathrm{HS}$ catalysts supported on alumina prepared by hydrothermal synthesis was superior than the other catalysts, which were mainly due to the moderate metal particle size, the enhanced synergic between $\mathrm{Rh}$ and $\mathrm{Fe}$, and the improved the $\mathrm{Rh}$ dispersion. Moreover, moderate $\mathrm{CO}$ hydrogenation rate, stronger $\mathrm{CO}$ dissociation and $\mathrm{CO}$ insertion ability was also favorable to increase the ethanol selectivity. 


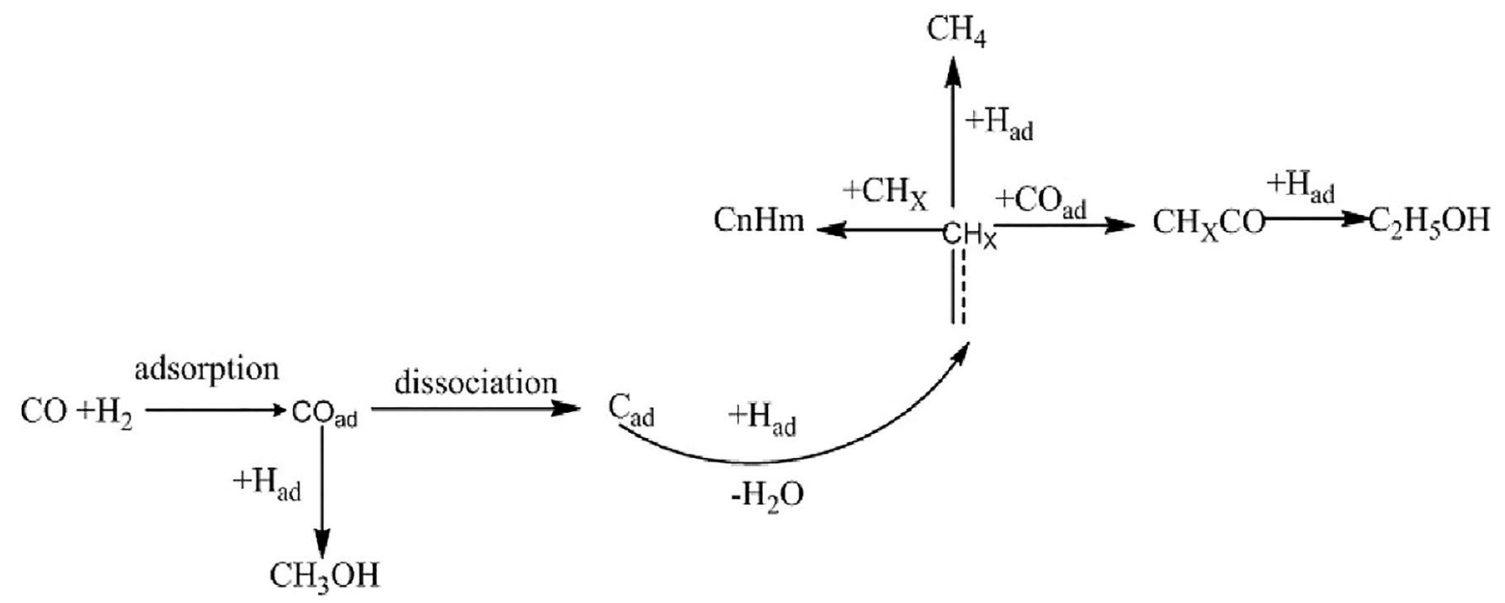

Fig. 11 Mechanism of ethanol formation [25]

Acknowledgements This work was supported by the National Natural Science Foundation of China (No. 31671797).

Open Access This article is licensed under a Creative Commons Attribution 4.0 International License, which permits use, sharing, adaptation, distribution and reproduction in any medium or format, as long as you give appropriate credit to the original author(s) and the source, provide a link to the Creative Commons licence, and indicate if changes were made. The images or other third party material in this article are included in the article's Creative Commons licence, unless indicated otherwise in a credit line to the material. If material is not included in the article's Creative Commons licence and your intended use is not permitted by statutory regulation or exceeds the permitted use, you will need to obtain permission directly from the copyright holder. To view a copy of this licence, visit http://creativecommons.org/licenses/by/4.0/.

\section{References}

1. Kang J, He S, Zhou W, Shen Z, Li Y, Chen M, Zhang Q, Wang $Y$ (2020) Single-pass transformation of syngas into ethanol with high selectivity by triple tandem catalysis. Nat Commun 11:827

2. Wang CT, Zhang J, Qin GQ (2020) Direct conversion of syngas to ethanol within zeolite crystals. ChemCatChem 6:646-657

3. Wang J, Zhong H, An K, Liu Q, Jin W (2020) Co-Ni alloy nanoparticles on la-doped $\mathrm{SiO}_{2}$ for direct ethanol synthesis from syngas. Ind Eng Chem Res 59:19539-19552

4. Haider MA, Gogate MR, Davis RJ (2009) Fe-promotion of supported $\mathrm{Rh}$ catalysts for direct conversion of syngas to ethanol. J Catal 261:9-16

5. Fang L, Qian WX (2017) Effect of Fe impregnation sequence on ethanol synthesis from syngas over $\mathrm{Mn}$ and Fe promoted $\mathrm{Rh} / \gamma-\mathrm{Al}_{2} \mathrm{O}_{3}$. Appl Petrochem Res 7:161-167

6. Liu W, Wang S, Sun T, Wang S (2015) The promoting effect of $\mathrm{Fe}$ doping on $\mathrm{Rh} / \mathrm{CeO}_{2}$ for the ethanol synthesis. Catal Lett 145:1741-1749

7. Xu D, Zhang H, Ma H, Qian W, Ying W (2017) Effect of Ce promoter on $\mathrm{Rh}-\mathrm{Fe} / \mathrm{TiO}_{2}$ catalysts for ethanol synthesis from syngas. Catal Commun 98:90-93

8. Fukushima T, Arakawa H, Ichikawa M (1985) In situ highpressure FT-IR studies on the surface species formed in carbon monoxide hydrogenation on silicon dioxide-supported rhodiumiron catalysts. J Phys Chem 89:4440-4443

9. Chen WM, Ding YJ, Song XG, Wang T, Luo HY (2011) Promotion effect of support calcination on ethanol production from $\mathrm{CO}$ hydrogenation over $\mathrm{Rh} / \mathrm{Fe} / \mathrm{Al}_{2} \mathrm{O}_{3}$ catalysts. Appl Catal A 407:231-237

10. Burch R, Hayes MJ (1997) The preparation and characterisation of Fe-promoted $\mathrm{Al}_{2} \mathrm{O}_{3}$-supported $\mathrm{Rh}$ catalysts for the selective production of ethanol from syngas. J Catal 165:249-261

11. García-Diéguez M, Pieta IS, Herrera MC, Larrubia MA, Malpartida I, Alemany LJ (2010) Transient study of the dry reforming of methane over Pt supported on different $\gamma-\mathrm{Al}_{2} \mathrm{O}_{3}$. Catal Today 149:380-387

12. Zhang MH, Fan JY, Chi K, Duan AJ, Zhao Z, Meng XL, Zhang HL (2017) Synthesis, characterization, and catalytic performance of NiMo catalysts supported on different crystal alumina materials in the hydrodesulfurization of diesel. Fuel Process Technol 156:446-453

13. Yu J, Mao DS, Han LP, Guo QS, Lu GZ (2012) The effect of Fe on the catalytic performance of Rh-Mn- $\mathrm{Li} / \mathrm{SiO}_{2}$ catalyst: a DRIFTS study. Catal Commun 27:1-4

14. Kang C, Jing L, Guo T, Cui H, Zhou J, Fu H (2008) Mesoporous $\mathrm{SiO}_{2}$-modified nanocrystalline $\mathrm{TiO}_{2}$ with high anatase thermal stability and large surface area as efficient photocatalyst. J Phys Chem C 113:1006-1013

15. Tsyganenko AA, Mardilovich PP (1996) Structure of alumina surfaces. J Chem Soc 92:4843-4852

16. Yang XM, Wei Y, Su YL, Zhou LP (2010) Characterization of fused $\mathrm{Fe}-\mathrm{Cu}$ based catalyst for higher alcohols synthesis and DRIFTS investigation of TPSR. Fuel Process Technol 91:1168-1173

17. Chen WM, Ding Y, Jiang DH, PanLuo ZDHY (2005) An effective method of controlling metal particle size on impregnated Rh-Mn$\mathrm{Li} / \mathrm{SiO}_{2}$ catalyst. Catal Lett 104:177-180

18. Han Y-F, Zhong Z, Ramesh K, Chen F, Chen L (2007) Effects of different types of $\gamma-\mathrm{Al}_{2} \mathrm{O}_{3}$ on the activity of gold nanoparticles for CO oxidation at low-temperatures. J Phys Chem C 111:3163-3170

19. Mo XH, Gao J, Goodwin JG Jr (2009) Role of promoters on Rh/ $\mathrm{SiO}_{2}$ in $\mathrm{CO}$ hydrogenation: a comparison using DRIFTS. Catal Today 147:139-149

20. Prieto G, Concepción P, Martínez A, Mendoza E (2011) New insights into the role of the electronic properties of oxide

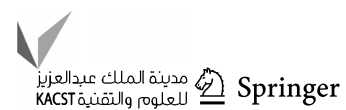


promoters in Rh-catalyzed selective synthesis of oxygenates from synthesis gas. J Catal 280:274-288

21. Basu P, Panayotov D, Yates JT (1988) Rhodium-carbon monoxide surface chemistry: the involvement of surface hydroxyl groups on $\mathrm{Al}_{2} \mathrm{O}_{3}$ and $\mathrm{SiO}_{2}$ supports. J Am Chem Soc 110:2074-2076

22. Mo XH, Gao J, Umnajkaseam N, Goodwin JG (2009) La, V, and Fe promotion of $\mathrm{Rh} / \mathrm{SiO}_{2}$ for $\mathrm{CO}$ hydrogenation: effect on adsorption and reaction. J Catal 267:167-176

23. Wang Y, Luo HY, Liang DB, Bao XH (2000) Different mechanisms for the formation of acetaldehyde and ethanol on the $\mathrm{Rh}-$ based catalysts. J Catal 196:46-55
24. Egbebi A, Schwartz V, Overbury SH, Spivey JJ (2010) Effect of Li promoter on titania-supported Rh catalyst for ethanol formation from CO hydrogenation. Catal Today 149:91-97

25. Ichikawa M, Fukushima T (1985) Mechanism of syngas conversion into $\mathrm{C}_{2}$-oxygenates such as ethanol catalysed on a $\mathrm{SiO}_{2}$-supported $\mathrm{Rh}$-Ti catalyst. J Chem Soc Chem Commun $6: 321-323$

Publisher's Note Springer Nature remains neutral with regard to jurisdictional claims in published maps and institutional affiliations. 